\title{
PENGARUH PENILAIAN KERJA TERHADAP MOTIVASI KERJA PEGAWAI PADA BAGIAN ADMINISTRASI PEMBANGUNAN DI KABUPATEN PESA WARAN
}

\author{
Dodi Susilo $^{(1)}$, Ahiruddin ${ }^{(2)}$,Sodirin ${ }^{(3)}$ \\ Fakultas Ekonomi Universitas Sang Bumi Ruwa Jurai \\ susilo_dodi30@gmail.com,ahiruddin@fe.saburai.ac.id,sodirin@fe.saburai.ac.id
}

\begin{abstract}
Abstrak. Penelitian ini bertujuan untuk mengetahui pengaruh penilaian kerja terhadap motivasi kerja pegawai pada Bagian Administrasi Pembangunan di Kabupaten Pesawaran.Permasalahan dalam penelitian ini adalah Penilaian kerja yang tidak sesuai dengan yang semestinya, Motivasi kerja pegawai rendah dan Penilaian kerja yang tidak sesuai dengan aturan yang ada. Hipotesis dalam penelitian ini adalah diduga penilaian kerja berpengaruh terhadap motivasi kerja pada Bagian Administrasi Pembangunan di Kabupaten Pesawaran.Metode Penelitian dalam penelitian ini adalah analisa kuantitatif, pengumpulan data yang digunakan berupa data primer dan data sekunder. Teknik pengumpulan data yang digunakan adalah observasi, wawancaraa, dokumentasi dan quisioner/ daftar pertanyaan. Teknik sampel akan ditentukan dari jumlah responden sebanyak 25 orang responden pegawai pada Bagian Administrasi Pembangunan di Kabupaten Pesawaran.Dari hasil penelitian dinyatakan bahwa Penilaian Kerja (X) pada pegawai Bagian Administrasi Pembangunan di Kabupaten Pesawaran dalam kategori baik. Hasil perhitungan tingkat korelasi antara variabel Penilaian Kerja (X) dan variabel Motivasi Kerja (Y) Bagian Administrasi Pembangunan di Kabupaten Pesawaran adalah sebesar 0,412, termasuk dalam kategori sedang yakni $(0,400-0,599)$. Besarnya Koefisien Determinasi antara Penilaian Kerja (X) dengan Motivasi Kerja $(\mathrm{Y})$ adalah $(\mathrm{KD})=\mathrm{R}^{2}=$ $0,32^{2}=0.1024=0,1024 \times 100 \%=10,24 \%$. Uji hipotesis parsial melalui uji $\mathrm{t}$ (test) diperoleh nilai $\mathrm{t}_{\text {hitung }}$ antara Penilaian Kerja (X) dengan Variabel Motivasi Kerja (Y) sebesar $=1,755$ dan $t_{\text {hitung }} 1,755>t_{\text {tabel }} 1,71$. Persamaan regresi antara Penilaian Kerja dengan Motivasi Kerja Bagian Administrasi Pembangunan di Kabupaten Pesawaran adalah $\mathrm{Y}=2,807+0,272 \mathrm{X}$, yang artinya setiap kenaikan satu point dari variabel Penilaian Kerja akan diikuti oleh variabel Motivasi Kerja sebesar 0,272 point. Hal ini menunjukkan bahwa Penilaian Kerja memberikan kontribusi dalam meningkatkan Motivasi Kerja.
\end{abstract}

Kata kunci : Penilaian Kerja, Motivasi Kerja, Disiplin.

\section{PENDAHULUAN}

Dalam suatu sistem organisasi, potensi Sumber Daya Manusia pada hakekatnya merupakan salah satu modal dan memegang suatu peran yang paling penting dalam mencapai tujuan organisasi. Oleh karena itu organisasi perlu mengelola Sumber Daya Manusia sebaik mungkin. Sebab kunci sukses suatu organisasi bukan hanya pada keunggulan teknologi dan tersedianya dana saja. Tapi faktor manusia merupakan faktor yang terpenting pula.
Penilaian kerja pada dasarnya
merupakan faktor kunci guna mengembangkan suatu organisasi secara efektif dan efisien, karena adanya kebijakan atau program yang lebih baik atas sumber daya manusia yang ada dalam organisasi. Penilaian kinerja individu sangat bermanfaat bagi dinamika pertumbuhan organisasi secara keseluruhan, melalui penilaian tersebut maka dapat diketahui kondisi sebenarnya tentang bagaimana kinerja pegawai.

Menurut Dessler (2015: 322) "penilaian kerja berarti mengevaluasi 
kinerja pegawai saat ini dan dimasa lalu relatif terhadap standar prestasinya". Apabila dikaitkan dengan performance sebagai kata benda (noun), maka pengertian performance atau kinerja adalah hasil kerja yang dapat dicapai oleh seseorang atau kelompok orang dalam suatu perusahaan sesuai dengan wewenang dan tanggung jawab masing-masing dalam upaya pencapaian tujuan perusahaan secara legal, tidak melanggar hukum dan tidak bertentangan dengan moral dan etika.

Menurut Dessler (2015: 326) Ada beberapa alasan untuk menilai kinerja bawahan. Pertama, penilaian harus memainkan peran yang terintegrasi dalam proses manajemen kinerja pengusaha. Kedua penilaian memungkinkan atasan dan bawahan menyusun sebuah rencana untuk mengoreksi semua kekurangan yang ditemukan dalam penilain dan menegaskan hal-hal yang telah dilakukan benar oleh pegawai. Ketiga, penilaian harus melayani tujuan perencanaan karir dengan meninjau rencana karir dari para pegawai dengan memperhatikan kekuatan dan kelemahan secara spesifik.

Dessler (2015: 326) menyatakan penilaian kerja merupakan metode mengevaluasi dan menghargai kinerja yang paling umum digunakan. Dalam penilaian kinerja melibatkan komunikasi dua arah yaitu antara pengirim pesan dengan penerima pesan sehingga komunikasi dapat berjalan dengan baik. Penilaian kinerja dilakukan untuk memberi tahu pegawai apa yang diharapkan pengawas untuk membangun pemahaman yang lebih baik satu sama lain. Penilaian kinerja menitik beratkan pada penilaian sebagai suatu proses pengukuran sejauh mana kerja dari orang atau sekelompok orang dapat bermanfaat untuk mencapai tujuan yang ada.

Menurut Hasibuan (2015: 67) penilaian kerja merupakan penilaian yang meliputi penilaian kesetiaan, kejujuran kepemimpinan, kerja sama, loyalitas, dedikasi dan partisipasi pegawai. Selain itu penilaian kinerja menurut Kreitner dan Kinicki dalam Wibowo (2014:391) membahas bahwa motivasi dapat diperoleh melalui kebutuhan, desain pekerjaan, kepuasan, keadilan, harapan dan penetapan tujuan.

Tabel Jumlah Pegawai dan Tingkat Pendidikan Pegawai Bagian Administrasi Pembangunan di Kabupaten Pesawaran Tahun 2017

\begin{tabular}{|l|l|l|}
\hline No & Pendidikan & Jumlah \\
\hline 1 & SD & - \\
\hline 2 & SMP & - \\
\hline 3 & SMA & 5 \\
\hline 4 & D3 & 5 \\
\hline 5 & S1 & 10 \\
\hline 6 & S2 & 5 \\
\hline \multicolumn{2}{|l}{ JUMLAH } & 25 \\
\hline
\end{tabular}

Sumber: Bagian Administrasi Pembangunan di Kabupaten Pesawaran (2018)

Berdasarkan tabel di atas menunjukan bahwa jumlah pegawai yang ada di Bagian Administrasi Pembangunan di Kabupaten Pesawaran sebanyak 25 pegawai dan tabel di atas juga menunjukan tingkat pendidikan di tahun 2017, yaitu terdiri dari 5 pegawai yang berpendidikan SMA, 5 pegawai yang berpendidikan D3, 10 pegawai yang berpendidikan $\mathrm{S} 1$, dan 5 pegawai yang berpendidikan S2 pada tahun 2017. Tabel tersebut menunjukkan bahwa tingkat pendidikan pegawai cukup untuk mendukung hasil kerja pegawai Bagian Administrasi Pembangunan di Kabupaten Pesawaran.

Latar belakang pengambilan Pembangunan di Kabupaten Pesawaran adalah penilaian kinerja dan motivasi kerja individu Pegawai yang ada di Bagian Administrasi Pembangunan di Kabupaten Pesawaran sangat penting untuk dikaji dan perlu perbaikan di masa yang akan datang. Pada Bagian Administrasi Pembangunan di 
Kabupaten Pesawaran penilaian kerja pegawainya terutama bila dilihat dari segi kehadiran pegawai ini sendiri apakah dapat berpengaruh pada peningkatan kinerja pegawai dengan pemberian motivasi dari atasan kepada pegawainya. Tentunya dengan dimudahkannya akses penilaian kinerja dan pemberian motivasi ini diharapkan dapat berpengaruh pada produktivitas dari pegawai Bagian Administrasi Pembangunan di Kabupaten Pesawaran itu sendiri, dari ketepatan waktu kedatangan saat bekerja hingga waktu istirahat dan kepulangan dari pegawai tersebut. Berdasarkan uraian latar belakang, maka penulis melakukan penelitian yang berjudul: "Pengaruh Penilaian Kerja Terhadap Motivasi Kerja Pegawai pada Bagian Administrasi Pembangunan di Kabupaten Pesawaran".

\section{KAJIAN TEORI}

\section{Manajemen Sumber Daya Manusia}

Griffin (2013 : 8) mengemukakan bahwa manajemen adalah suatu rangkaian aktivitas (termasuk perencanaan dan pengambilan keputusan, pengorganisasian, kepemimpinan dan pengendalian) yang diarahkan pada sumber-sumber daya organisasi (manusia, finansial, fisik dan informasi) untuk mencapai tujuan organisasi dengan cara yang efektif dan efisien. Efektif yang dimaksud dalam manajemen adalah menggunakan sumbersumber daya secara bijaksana dan dengan cara yang hemat biaya, sementara efisien berarti bahwa pembuatan keputusan dilakukan secara tepat dan diimplementasikan dengan kesuksesan.

Manajemen ini terdiri dari tujuh unsur (7M) yaitu: man, money, methode, materials, machines, market dan mischelenous (informasi dan lingkungan).
Unsur men (manusia) ini berkembang menjadi suatu bidang ilmu manajemen yang disebut Manajemen Sumber Daya Manusia yang merupakan terjemahan dari Human Resource Management. Manajemen yang mengatur unsur manusia ini dahulu dikenal dengan istilah manajemen kepegawaian atau manajemen personalia (personnel management). Persamaan manajemen sumber daya manusia dengan manajemen personalia adalah keduanya merupakan ilmu yang mengatur unsur manusia dalam suatu organisasi, agar mendukung terwujudnya tujuan.

\section{Pengertian Penilaian Kerja}

$\begin{array}{ccr}\text { Penilaian } & \text { kerja mempunyai } \\ \text { beberapa istilah } & \text { seperti } & \text { employee }\end{array}$ evaluation, employee rating, personal appraisal dan performance appraisal merupakan suatu kegiatan evaluasi yang dilakukan oleh perusahaan terhadap prestasi kerja pegawai.

Penilaian kerja pegawai merupakan salah satu bentuk kebijakan manajemen perusahaan untuk terus merevisi sumber daya manusia yang dimilikinya dengan cara membandingkan hasil kerja para pegawai dengan deskripsi pekerjaan yang telah ditetapkan, dan membandingkan hasil kerja yang ada dengan harapan-harapan dari atasan. Biasanya kegiatan ini dilakukan dalam suatu periode tertentu.

Pengertian penilaian kerja yang dikemukakan Wahyudi (2010: 89) yaitu penilaian kinerja merupakan suatu evaluasi yang dilakukan secara periodic dan sistematis tentang prestasi kerja seoirang tenaga kerja, termasuk potensi pengembangannya. Sedangkan Yorder berpendapat "Personnel appraisal refers to evaluate the formal procedures used in working organization to evaluate the personalities and contributions and potential of group members" bahwa 
Penilaian prestasi kerja merupakan prosedur yang formal dilakukan dalam organisasi untuk mengevaluasi pegawai dan sumbangan serta kepentingan bagi pegawai.

\section{Tujuan Penilaian Kinerja}

Menurut Hasibuan (2015: 67), tujuan dan kegunaan penilaian prestasi kerja adalah sebagai berikut :

1. Sebagai dasar pengambilan keputusan yang digunakan untuk promosi dan penetapan besarnya balas jasa.

2. Untuk mengukur prestasi kerja yaitu sejauh mana pegawai bias sukses

3. Sebagai dasar untuk mengevaluasi efektivitas seluruh kegiatan.

4. Sebagai dasar untuk mengevaluasi program latihan dan keefektivan jadwal kerja, metode kerja, struktur organisasi, gaya pengawasan, kondisi kerja dan peralatan kerja.

5. Sebagai indikator untuk menetukan kebutuhan akan latihan bagi pegawai yang berada dalam organisasi.

6. Sebagai alat untuk meningkatkan motivasi kerja untuk mendapatkan performance kerja yang baik.

7. Sebagai alat untuk mendorong atau membiasakan para atasan (supervisor, manager, administrator) supaya diketahui minat dan kebutuhankebutuhan bawahannya.

8. Sebagai alat untuk melihat kekurangan atau kelemahan-kelemahan masa lalu dan meningkatkan kemampuan pegawai selanjutnya.

9. Sebagai kriteria di dalam menentukan seleksi dan penempatan pegawai.

10. Sebagai alat untuk mengidentifikasi kelemahan-kelemahan personel dan dengan demikian bias sebagai bahan pertimbangan agar diikut sertakan dalam program latihan kerja tambahan.

11. Sebagai alat untuk memperbaiki atau mengembangkan kecakapan pegawai.
12. Sebagai dasar untuk memperbaiki dan mengembangkan uraian pekerjaan (job description).

\section{METODE PENELITIAN}

\section{Objek Penelitian}

Penelitian ini mengambil lokasi di Bagian Administrasi Pembangunan di Kabupaten Pesawaran, yang beralamat di Komplek Perkantoran Pemerintah Kabupaten Pesawaran Jl. Raya Kedondong, Way Layap Kec. Gedong Tataan Kabupaten Pesawaran. Waktu penelitian dilakukan dari tanggal 1 April 2018 sampai dengan 1 Juni 2018.

\section{Metode dan Teknik Pengumpulan Data}

Data yang diperlukan dalam penelitian dapat berupa data sekunder dan data primer yang dikumpulkan dengan cara sebagai berikut :

1. Data Primer yaitu data yang dikumpulkan dan diolah sendiri oleh peneliti langsung dari responden. Dalam penelitian ini data primer diperoleh dengan cara memberikan angket (quisioner) kepada responden yaitu pegawai di Bagian Administrasi Pembangunan di Kabupaten Pesawaran

2. Data Sekunder yaitu data yang diperoleh dari pihak lain yang telah mengolah atau mempublikasikan data primer seperti diperoleh dari Jurnal, Majalah Ilmiah, Buletin dan sebagainya.

Penelitian ini dilakukan secara langsung dengan langkah-langkah :

a. Observasi, yaitu mengadakan pengamatan langsung pada obyek penelitian

b. Interview, yaitu untuk memperoleh data yang dinilai dapat melengkapi data pokok dengan serangkaian wawancara 
c. Kuesioner, yaitu tehnik pengumpulan data primer dengan cara mengajukan beberapa pernyataan secara tertulis dengan alternatif Jawaban yang diajukan kepada responden

d. Dokumentasi, yaitu tehnik pengumpulan data dengan cara mengumpulkan melalui buku, jurnal dan tulisan yang ada hubungannya dengan permasalahan yang diteliti

\section{Sampel dan Populasi}

Menurut pendapat Suharsimi Arikunto (2013:108) bahwa jika anggota populasi lebih besar dari 100 maka dapat dilakukan metode sampling dengan mangambil sampel sebesar 10 sd $25 \%$ dari anggota populasi, tetapi jika anggota populasi lebih kecil dari 100 sebaiknya menggunakan metode sensus dengan meneliti seluruh anggota populasi Jumlah pegawai Pada Bagian Administrasi Pembangunan di Kabupaten Pesawaran adalah 25 orang.

\section{Metode Penelitian}

Analisis kualitatif dilakukan dengan analisis tabel tunggal atau secara parsial yang menggambarkan kriteria masingmasing variabel independent, dalam penelitian ini yaitu varibel Penilaian Kerja (X). dan variabel dependent yaitu Motivasi Kerja (Y). Kriteria masing-masing variabel pada analisis tabel mengacu pada interval skor dengan rumus sebagai berikut :

$$
I=N T-\frac{N R}{J I}
$$

Keterangan :

I = Lebar interval

NT = Nilai tertinggi

$\mathrm{NR}=$ Nilai terendah

JI = Jumlah interval

(Sudjana, 2013:282)
Analisis kuantitatif yang digunakan dalam penelitian ini bertujuan untuk mengetahui Pengaruh Penilaian Kerja Terhadap Motivasi Kerja pada Bagian Administrasi Pembangunan Setda Kabupaten Pesawaran.

Untuk mengetahui keeratan Pengaruh Penilaian Kerja Terhadap Motivasi Kerja pada Bagian Administrasi Pembangunan di Kabupaten Pesawaran, penulis menggunakan rumus koefisien korelasi adalah :

$$
r_{x y}=\frac{n(\Sigma X i Y i)-(\Sigma X i) \cdot(\Sigma Y i)}{\{n \Sigma X i 2-(\Sigma X i) 2\}\{n \Sigma Y i 2-(\Sigma Y i) 2\}}
$$

\section{Keterangan :}

$r$ : Koefisien Korelasi

$\mathrm{X}_{\mathrm{i}}$ : Variabel Independen

$Y_{i}$ : Variabel Dependen

n : Jumlah sampel

( Sugiyono, $2012: 274$ )

Tabel Pedoman untuk memberikan interpretasi terhadap Koefisien Korelasi

\begin{tabular}{|l|l|}
\hline Interval Koefisien & Tingkat Hubungan \\
\hline $0,000-0,199$ & Sangat Rendah \\
$0,200-0,399$ & Rendah \\
$0,400-0,599$ & Sedang \\
$0,600-0,799$ & Kuat \\
$0,800-1,000$ & Sangat Kuat \\
\hline
\end{tabular}

Sumber : Sugiyono (2012:328)

Selanjutnya untuk menguji variabel secara sendiri-sendiri atauparsial digunakan Uji t dengan rumus sebagai berikut :

$$
t_{\text {hitung }}=r \sqrt{\frac{n-2}{1-r^{2}}}
$$

$$
\begin{array}{cl}
\text { Dimana : } & \mathrm{t}_{\text {hitung }}=\text { Nilai } \mathrm{t} \\
\mathrm{r} & =\text { Koefisien Korelasi } \\
\mathrm{n} & =\text { Jumlah responden }
\end{array}
$$

Kriteria untuk Uji t adalah sebagai berikut :

a) Jika $t_{\text {hitung }}>t_{\text {tabel }}$ maka Ha diterima dan Ho ditolak. 
b) Jika $t_{\text {hitung }} \leq t_{\text {tabel }}$ maka Ha ditolak dan Ho diterima.

Taraf signifikan dalam penelitian ini digunakan $\alpha=0,05$ atau 5\%.Yang dimaksud dengan Hipotesis nol (Ho) dan Hipotesis alternatif (Ha) adalah :

$$
\begin{aligned}
& \text { Ho }=\mathbf{r} \leq \mathbf{0}=\text { Berarti tidak ada Pengaruh } \\
& \text { Penilaian Kerja Terhadap } \\
& \text { Motivasi Kerja } \\
& \text { Ha }=\mathbf{r}>\mathbf{0}=\text { Berarti ada Pengaruh } \\
& \text { Penilaian Kerja Terhadap } \\
& \text { Motivasi Kerja }
\end{aligned}
$$

Untuk mengetahui apakah variabel bebas secara bersama-sama (simultan) memiliki pengaruh terhadap variabel terikat digunakan Uji F .

Dalam hal ini F-hitung dibandingkan dengan F-tabel dengan syarat sebagai berikut:

1. Jika $F_{\text {hitung }}>F_{\text {tabel, }}$ maka Ho ditolak dan Ha diterima.

2. Jika $F_{\text {hitung }}<F_{\text {tabel }}$ maka Ho diterima dan Ha ditolak.

Hasil pengujian signifikansi dapat juga dilihat dari besarnya nilai signifikansi yang diperoleh yaitu:

1. Jika nilai signifikansi < dari 0,05 maka Ho ditolak dan Ha diterima.

2. Jika nilai signifikansi > dari 0,05 maka Ho diterima dan Ha ditolak

\section{HASIL DAN PEMBAHASAN}

\section{Analisis Regresi Linier antara Penilaian

\begin{tabular}{|c|c|c|c|}
\hline & $\begin{array}{l}\text { Sig. (1-tailed) } \\
\mathrm{N}\end{array}$ & 25 & $\begin{array}{l}.064 \\
25\end{array}$ \\
\hline Y & \begin{tabular}{l|} 
Pearson \\
Correlation
\end{tabular} & & \\
\hline & Sig. (1-tailed) & .064 & \\
\hline & $\mathrm{N}$ & 25 & 25 \\
\hline
\end{tabular} Kerja (X) Terhadap Motivasi Kerja (Y)}

Tabel Hasil Uji Korelasi Penilaian Kerja (X) dengan Motivasi Kerja (Y)

Correlations

\begin{tabular}{|ll|l|l|}
\hline & & $\mathrm{X}$ & $\mathrm{y}$ \\
\hline $\mathrm{X}$ & $\begin{array}{l}\text { Pearson } \\
\text { Correlation }\end{array}$ & 1 & .312 \\
\hline
\end{tabular}

Berdasarkan hasil perhitungan tingkat korelasi antar variabel pada Tabel 4.8 diatas, diperoleh besarnya tingkat korelasi antara variabel Penilaian Kerja (X) dengan Variabel Motivasi Kerja (Y) Bagian Administrasi Pembangunan di Kabupaten Pesawaran adalah sebesar 0,412. Jika dikonsultasikan dengan tabel Interpretasi Koefesien Korelasi maka tingkat korelasi Penilaian Kerja (X) dengan Variabel Motivasi Kerja (Y) Bagian Administrasi Pembangunan di Kabupaten Pesawaran termasuk dalam kategori korelasi "sedang" yakni terletak pada $(0,400-0,599)$.

Berdasarkan hasil penelitian di atas,

\begin{tabular}{|c|c|c|c|c|}
\hline \multicolumn{4}{|c|}{ Model Summary } & \\
\hline Model & $\mathbb{R}$ & $\begin{array}{l}\mathrm{R} \\
\text { Square }\end{array}$ & $\begin{array}{l}\text { Adjuste } \\
\text { d } \\
\text { Square }\end{array}$ & \begin{tabular}{|l|} 
Std. \\
Error \\
of the \\
Estimat \\
e
\end{tabular} \\
\hline \begin{tabular}{|l|l|}
$\operatorname{dimen}$ & 1 \\
$\operatorname{sion} 0$
\end{tabular} & $.032 \mathrm{a}$ & .097 & .058 & .43130 \\
\hline \multicolumn{4}{|c|}{ a. Predictors: (Constant), X } & \\
\hline
\end{tabular}
maka diperoleh Koefisien Determinasi Penilaian Kerja (X) dengan Variabel Motivasi Kerja (Y) adalah sebagai berikut :

Tabel Koefisien Determinasi Penilaian Kerja (X) dengan Motivasi Kerja (Y)

Koefisien Determinasi $(\mathrm{KD})=\mathrm{R} 2=$ $0,322=0.1024=0,1024 \times 100 \%=10,24$ $\%$. Dapat disimpulkan bahwa variabel Penilaian Kerja (X) menjelaskan variasi perubahan variabel Motivasi Kerja (Y) sebesar10,24\%, sedangkan sisanya dijelaskan oleh faktor lain yang tidak dikaji dalam penelitian ini. 
Berdasarkan hasil penelitian, maka diperoleh data Hubungan Penilaian Kerja (X) dengan Motivasi Kerja (Y) sebagai berikut : Tabel Uji Hipotesis Penilaian Kerja (X) dengan
Variabel Motivasi Kerja (Y)

Coefficientsa

\begin{tabular}{|c|c|c|c|c|c|}
\hline \multirow[t]{2}{*}{ Model } & \multicolumn{2}{|c|}{$\begin{array}{l}\text { Unstandardized } \\
\text { Coefficients }\end{array}$} & $\begin{array}{l}\text { Standard } \\
\text { ized } \\
\text { Coeffici } \\
\text { ents }\end{array}$ & \multirow[t]{2}{*}{. } & \\
\hline & B & \begin{tabular}{|l} 
Std. \\
Error
\end{tabular} & Beta & & Sig. \\
\hline $\begin{array}{ll}1 & \begin{array}{l}\text { (Const } \\
\text { ant })\end{array}\end{array}$ & 2.807 & .649 & & 4.324 & .000 \\
\hline $\mathrm{X}$ & .272 & .173 & .312 & 1.755 & .129 \\
\hline
\end{tabular}

a. Dependent Variable: y

Berdasarkan hasil Uji t didapat nilai thitung $=1,755$. Apabila dibandingkan dengan ttabel pada taraf signifikan yaitu 1,71 , maka thitung $=1,755>$ ttabel $=1,71$, sehingga dapat disimpulkan bahwa; Hipotesis yang menyatakan terdapat pengaruh antara Variabel Penilaian Kerja (X) dengan Motivasi Kerja (Y) pada Bagian Administrasi Pembangunan di Kabupaten Pesawaran dapat diterima. Jadi variabel Penilaian Kerja (X) berhubungan dengan Motivasi Kerja (Y) pada Bagian Administrasi Pembangunan di Kabupaten Pesawaran .

Persamaan regresi antara variabel Penilaian Kerja (X) terhadap Motivasi Kerja $(\mathrm{Y})$ adalah $\mathrm{Y}=2,807+0,272 \mathrm{X}$, yang artinya setiap kenaikan satu point dari variabel Penilaian Kerja akan diikuti oleh variabel Motivasi Kerja sebesar 0,272 point.

\section{KESIMPULAN DAN SARAN}

\section{Kesimpulan}

Berdasarkan analisis dan pembahasan maka dapat diambil kesimpulan hádala hasil perhitungan tingkat korelasi antara variabel Penilaian Kerja (X) dan variabel Motivasi Kerja (Y) Bagian Administrasi Pembangunan di Kabupaten Pesawaran adalah sebesar 0,412 , termasuk dalam kategori sedang yakni $(0,400 \quad-$ 0,599), Besarnya Koefisien Determinasi antara Penilaian Kerja (X) dengan Motivasi Kerja (Y) adalah $(\mathrm{KD})=\mathrm{R} 2=$ $0,322=0.1024=0,1024 \times 100 \%=10,24$ $\%$..

Berarti hubungan motivasi terhadap Motivasi Kerja adalah sebesar 10,24 \%, Persamaan regresi antara Penilaian Kerja dengan Motivasi Kerja Bagian Administrasi Pembangunan di Kabupaten Pesawaran adalah $\mathrm{Y}=2,807+0,272 \mathrm{X}$, yang artinya setiap kenaikan satu point dari variabel Penilaian Kerja akan diikuti oleh variabel Motivasi Kerja sebesar 0,272 point. Hal ini menunjukkan bahwa Penilaian Kerja memberikan kontribusi dalam meningkatkan Motivasi Kerja.

\section{Saran}

Berdasarkan hasil penelitian, pembahasan, dan kesimpulan yang diperoleh, maka saran yang dapat diberikan sebagai berikut.

1. Variabel penilaian kerja mempunyai hubungan terhadap Motivasi Kerja pegawai. Oleh karena itu hendaknya semua pihak yang ada dalam organisasi, mulai dari pimpinan tertinggi hingga pegawai di tingkat yang paling rendah dapat sama-sama berupaya untuk terus memotivasi diri dan menjalankan pekerjaan yang telah disepakati bersama sehingga suasana menjadi kondusif.

2. Bagi peneliti selanjutnya dapat mengembangkan model dengan baik, menambah variabel yang lain tentang faktor-faktor lain yang mungkin 
mempunyai hubungan dengan Motivasi Kerja, dengan memperluas jumlah sampel dan lokasi penelitian,

\section{DAFTAR PUSTAKA}

Lamazio, M. Aziz. 2013. Strategi Promosi Jasa Perjalanan Haji dan Umroh Melalui Media Website. Jurnal Manajemen Dakwah. Semarang: , Univesitas Islam Negeri Walisongo.

Robbins, S.P dan Timothy A. Judge. 2015. Perilaku Organisasi, Edisi 16. Jakarta: Indeks

Gregory dan Ricky W. Griffin. 2013. Perilaku Organisasi. Jakarta: Salemba Empat

Raymond A Noe, dkk, 2013, "Manjemen Sumber Daya Manusia” Edisi 6, Bukul \& 2, Jakarta : Salemba Empat

Ujang Muhyidin. Pengaruh Bauran Pemasaran Jasa Pendidikan Terhadap Keputusan Mahasiswa Memilih Perguruan Tinggi Swasta Di Jawa Barat. Jurnal: ISBN: 978979-3649-81-8.

Sis Rahardjo dan Muhammad Riza Firdaus. 2015.Analisis Pengaruh Bauran Pemasaran Status Sosial Ekonomi Dan Motivasi Terhadap Keputusan Mahasiswa Dalam Memilih Kuliah (Studi Pada Lembaga Pendidikan dan Pengembangan Profesi Indonesia (LP3I) Business College - Cabang Banjarmasin). Jurnal Wawasan Manajemen,Vol. 3, Nomor 1, Februari 2015.
Suharsimi Arikunto. 2013. Prosedur Penelitian suatu Pendekatan Praktik. Jakarta: Rineka Cipta.

Sujarweni, Wiratna. 2015. SPSS Untuk Penelitian. Yogyakarta : Pustaka Baru.

Kamilina, Rodhiyah, dkk. 2014. Penerapan Promotional Mix Pada Biro Perjalanan Umroh/Haji Shafira Tour and Travel Surabaya. Jurnal Ekonomi dan Bisnis. Surabaya: Univesitas Airlangga

Arikunto, Suharsimi, 2006. Prosedur Penelitian: Suatu Pendekatan Praktik, Edisi Revisi, Cetakan Ketigabelas. Jakarta: Penerbit Rineka Cipta.

Sugiyono. 2014. Metode Penelitian Kuantitatif Kualitatif dan $R \& D$. Bandung: Alfabeta. 